\title{
IMPLEMENTASI MANAJEMEN KEUANGAN KELUARGA DI MASA PANDEMI COVID-19 DENGAN PERSPEKTIF EKONOMI SYARIAH
}

\author{
M Arsyil Azhim 1)*, Muhammad Iqbal Fasa ${ }^{2)}$, Prof Suharto ${ }^{3)}$ \\ 1) Arsilazhim58@gmail.com, Universitas Raden Intan Lampung \\ 2) \\ 3) prof.suharto@radenintan.ac.id,Universitas Raden Intan Lampung \\ *penulis korespondensi
}

\begin{abstract}
Abstrak
The purpose of this study is to discuss how to implement Islamic financial management in Muslim families during the covid-19 pandemic. So, to analyze the data using data that has been obtained in the form of previous research, then the data analyzed is categorized and interpreted using perspective using documentary analysis. The result of this study is that family financial management is very important for the welfare of each individual and family in everyday life. Islamic financial management is management by determining the priority scale and household budget. The steps we take in managing family finances are as follows: (1) recording assets/assets owned, (2) recording all income and expenses, (3) identifying routine, monthly, and annual expenses, (4) drawing up an expenditure plan. (5) saving periodically. The key to success in managing family finances in a healthy state are: Basically, measuring household financial health is how we commit to implementing what has been planned above, because if we can't commit to household finances, then household finances are in an unhealthy state, so we cannot carry out financial planning as we planned.
\end{abstract}

Keywords: Covid 19, Family Financial Management, Sharia economic

\begin{abstract}
Abstrak
Tujuan dari penelitian ini membahas mengenai bagaimana implementasi pengelolaan keuangan secara Islam pada keluarga muslim di masa pandemi covid-19. Penelitian ini merupakan penelitian kualitatif deskriptif. Maka untuk menganalisis data menggunakan data yang telah diperoleh dalam bentuk penelitian sebelumnya kemudian data tersebut dianalisis dikategori sasi dan ditafsirkan dengan menggunakan perspektif dengan menggunakan analisis documenter. Hasil dari penelitian ini adalah pengelolaan keuangan keluarga sangat penting bagi kesejahteraan setiap individu dan keluarga dalam kehidupan sehari-hari. pengelolaan keuangan Islami adalah pengelolaan dengan menentukan skala prioritas dan anggaran belanja rumah tangga. Langkah-langkah yang kita lakukan dalam mengelola keuangan keluarga adalah sebagai berikut: (1) mencatat aset/harta yang dimiliki, (2) mencatat semua pemasukan dan pengeluaran, (3) identifikasi pengeluaran rutin, bulanan, dan tahunan, (4) menyusun rencana pengeluaran, (5) menabung secara periodik. Kunci keberhasilan dalam mengelola keuangan keluarga dalam keadaan sehat yaitu: Pada dasarnya mengukur kesehatan keuangan rumah tangga adalah bagaimana cara kita berkomitmen untuk melaksanakan apa yang telah direncanakan diatas, karena jika kita tidak bisa komitmen terhadap keuangan rumah tangga, maka keuangan rumah tangga dalam keadaan tidak sehat, dengan begitu kita tidak dapat melaksanakan perencanaan keuangan sesuai yang kita rencanakan.
\end{abstract}

Kata kunci : Covid 19, Ekonomi syariah, Manajemen keuangan keluarga

\section{PENDAHULUAN}

Permasalahan yang sering terjadi dalam sebuah rumah tangga, dan umumnya adalah seputar keuangan, seperti kekurangan uang atau kelebihan uang. Ketidaktahuan seseorang yang berpenghasilan pas-pasan, sedangkan kebutuhan melebihi pemasukan akan menjadi sumber malapetaka, sehingga banyak terjadi perceraian rumah tangga. Besar kecilnya penghasilan dalam keluarga, seharusnya dapat dikelola sebaik mungkin agar pengeluaran sesuai dengan pendapatan yang diterima (Ramli \& Apriyanto, 2020).

Dampak pada masa penyebaran virus covid-19 bukan saja masalah kesehatan akan tetapi turut mempengaruhi sektor ekonomi, sosial bahkan budaya di dalam masyarakat. Banyak pekerja yang harus "rela" diberhentikan sebagai akibat menurunnya produktifitas perusahaan tempat mereka bekerja (Hahury Fransisca, 2021). Kebijakan \#DiRumahAja untuk menekan laju kasus baru akibat covid-19 pada kurun waktu yang cukup lama, yang mengakibatkan keluarga terutama bergantung dengan upah harian mengalami penurunan penghasilan dan PHK. 
Saat ini hampir semua lini pekerjaan atau usaha mengalami penurunan ekonomi akibat covid19. Berdasarkan beberapa hasil penelitian menunjukkan, dampak pandemi covid-19 sangat berasa bagi keluarga. Survei dampak pandemi covid-19 terhadap ekonomi rumah tangga Indonesia yang dilakukan Lembaga Ilmu Pengetahuan Indonesia (LIPI) pada 10 -31 Juli 2020 menyimpulkan terjadinya ketidakstabilan kondisi perekonomian akibat pandemi covid-19 semakin dirasakan dalam kehidupan masyarakat Indonesia, khususnya rumah tangga (Rohaniah \& Rahmaini, 2021).

Dalam Islam sebuah keluarga itu diibaratkan sebuah bangunan, keluarga dibangun dari beberapa komponen yang menopangnya. Konstruksi pun harus dipersiapkan untuk menunjang kekuatan dan kekokohan pada bangunan keluarga. Di dalamnya ada suami, istri, dan kemungkinan juga ada anak-anak. Masing-masing memiliki peran yang berbeda demi mewujudkan sebuah keluarga yang diinginkan yaitu sakinah mawaddah warrahmah. Dalam Islam begitu pentingnya kedudukan sebuah keluarga. Melalui tempat tersebutlah seseorang mengetahui hak dan kewajiban sebagai hamba yang mempunyai tugas mengabdi kepada sang Khaliq (Al Hamat, 2018). Setiap yang sudah berkeluarga pasti menginginkan keluarganya sejahtera, karena dengan keluarga yang sejahtera yaitu ketika keluarga dapat menikmati hidup yang wajar, tercukupi kebutuhan materiil maupun spiritual dan semua anggota keluarga mendapat kesempatan seluas-luasnya untuk berkembang sesuai dengan kemampuan, bakat, dan potensi masing-masing lainnya. Gejolak perekonomian pada massa pandemi ini membuat masalah keuangan di dalam rumah tangga, sebagai ibu rumah tangga harus lebih pandai-pandai dalam mengelola manajemen keuangan keluarga. Penelitian mengenai manajemen keuangan di dalam rumah tangga itu sudah banyak dilakukan oleh peneliti-peneliti. Tetapi penelitian mengenai manajemen keuangan di dalam rumah tangga dengan perspektif Islam masih belum banyak peneliti yang meneliti.

(ARNESIH, 2016) melakukan mengenai strategi manajemen keuangan rumah tangga berbasis Islam. Hasil penelitian menunjukan bahwa. pada pembinaan kepribadian terhadap manajemen keuangan setiap rumah tangga muslim, pengembangan manajemen keuangan secara Islami, pengembangan pengamalan ajaran Islam khususnya dibidang ekonomi dan keuangan, dan pengembangan sosialisasi dan penyampaian kepada orang lain. Pentingnya mengelola keuangan dalam sebuah rumah tangga secara Islami dan dapat mengetahui keberadaan ekonomi yang sehat dalam sebuah rumah tangga dan mengelola pemberian Allah sesuai dengan fungsinya. Kemudian pada tahun 2020 (Ramli \& Apriyanto, 2020) melakukan penelitian mengenai manajemen keuangan untuk meningkatkan perekonomian keluarga di masa pandemi covid-19. Hasil penelitian ini sama halnya dengan penelitian (ARNESIH, 2016). Dengan adanya pemahaman yang baik tentang laporan keuangan keluarga, didukung oleh perencanaan yang baik, pembagian tugas dengan pasangan dan usaha menyiasati pengeluaran ekstra maka rumah tangga dapat melalui masalah-masalah keuangan keluarga dengan solusi yang benar. Hal terpenting adalah saling keterbukaan serta menjalani kehidupan keluarga dengan tanggung jawab bersama.

Dari penelitian-penelitian sebelumnya bahwa dapat disimpulkan manajemen keuangan di dalam rumah tangga adalah hal yang penting dilakukan agar terciptanya keharmonisan di dalam keluarga. Dan penelitian ini merujuk tentang pengelolaan keuangan keluarga yang benar dapat membantu masyarakat agar tidak panik menghadapi pandemi dan membantu dalam menjaga ketahanan ekonomi keluarga dalam perspektif ekonomi Islam. Adapun tujuan dari penelitian ini membahas mengenai bagaimana implementasi pengelolaan keuangan secara Islam pada keluarga muslim di masa pandemi covid-19. 


\section{KAJIAN PUSTAKA}

Pada dasarnya ajaran Islam yang tertuang dalam Al-Qur'an dan As Sunnah mengajarkan tentang kehidupan yang serba terarah dan teratur merupakan contoh konkrit adanya manajemen yang mengarah kepada keteraturan (Abdul Ghoffar, n.d.). Sudah menjadi kepastian, bahwa Al Quran dan Hadits menjadi referensi dan pandangan hidup dalam aspek kehidupan umat Islam seperti manajemen. Dalam sudut pandang Islam manajemen diistilahkan dengan menggunakan kata al-tadbir (pengaturan). Kata ini merupakan derivasi dari kata dab bara (mengatur) yang banyak terdapat dalam firman Allah SWT :

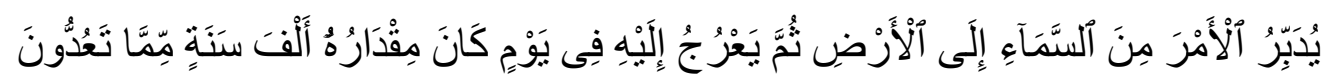

Artinya :

"Dia mengatur urusan dari langit ke bumi, kemudian (urusan) itu naik kepada-Nya dalam satu hari yang kadarnya adalah seribu tahun menurut perhitungan mu”. (QS As-Sajdah : 5 ).

Pada ayat di atas dapat memberikan makna bahwa Allah swt merupakan pengatur alam (Al Mudabbir/manager). Keteraturan alam raya ini merupakan bukti kebesaran Allah swt dalam mengelola alam ini. Namun, karena manusia yang diciptakan Allah SWT telah dijadikan sebagai khalifah di bumi, maka dia harus mengatur dan mengelola bumi dengan sebaik-baiknya sebagaimana Allah mengatur alam raya ini (Abdul Ghoffar, n.d.). Pengelolaan keuangan adalah tindakan administratif yang berhubungan dengan kegiatan perencanaan anggaran, penyimpanan, penggunaan, pencatatan dan pengawasan keluar masuknya uang. Pengelolaan keuangan dapat dilakukan oleh siapa saja, oleh karena itu, dibutuhkan keahlian manajemen keuangan yang baik, agar pengelolaan dapat berjalan dengan baik, kemampuan manajerial ini sangat diutamakan dimiliki oleh perempuan (Gustiawati Mukri \& Mulyadi Kosim, 2017). Mengenai konsep perencanaan dalam manajemen Al-Qur'an menjelaskan dalam surah AlHaysr ayat 18 :

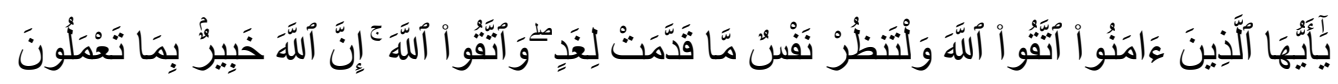

Artinya :

"Hai orang-orang yang beriman, bertakwalah kepada Allah dan hendaklah setiap diri memperhatikan apa yang telah diperbuatnya untuk hari esok (akhirat); dan bertakwalah kepada Allah, sesungguhnya Allah Maha Mengetahui apa yang kamu kerjakan”.

Pada penjelasan ayat diatas menerangkan bahwa perencanaan yang baik akan dicapai dengan mempertimbangkan kondisi di waktu yang akan datang dalam mana perencanaan dan kegiatan yang akan diputuskan akan dilaksanakan, serta periode sekarang pada saat rencana di buat. Perencanaan merupakan aspek penting dari pada manajemen (Abdul Ghoffar, n.d.)

Rumah tangga akan berjalan dengan baik apabila ada kerjasama antara suami dan istri atas pemenuhan hak dan kewajiban satu sama lain. Dalam rumah tangga, apa yang dimiliki suami itulah milik istri begitu pula sebaliknya. Sehingga inilah esensi dalam berumah tangga, yaitu kerja sama antar-anggota keluarga untuk mencapai tujuan yang sama. Di sinilah peran wanita diutamakan sebagaimana hadits (Inggriani \& Nafik HR, 2015).

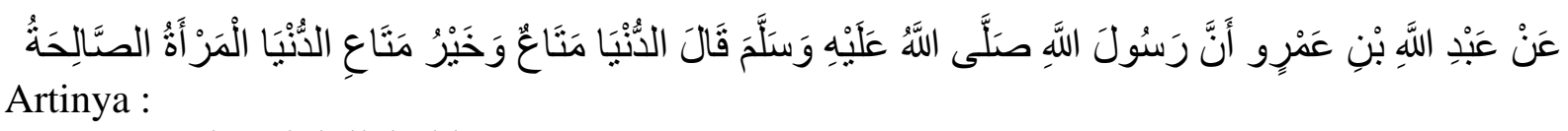
Artinya :

"Dari [Abdullah bin 'Amru] bahwasanya Rasulullah shall Allahu 'alaihi wasalam bersabda: "Dunia adalah perhiasan dan sebaik-baik perhiasan adalah wanita saliha"

Pada penjelasan hadis diatas peran wanita sangat penting dalam mengelola keuangan, mendidik anak, dan lain-lain. Dengan semakin berkembangnya kebutuhan manusia dan ditambah lagi di masa pandemi covid 19 ini sangat besar dampaknya terhadap perekonomian dan ditambah lagi diiringi berkembangnya berbagai kecanggihan teknologi dan membuat 
banyak perempuan juga turut andil bekerja. Walaupun hakikatnya harta suami adalah milik bersama, oleh sebab itu istri yang bijak adalah yang mampu mengatur keuangan rumah tangga dengan perencanaan dan pengalokasian dana secara tepat dengan mengutamakan kebutuhan primer. Harta seharusnya dikelola dan digunakan untuk hal-hal yang baik dan tidak menimbulkan kemurkaan Allah. Dengan kata lain mempergunakannya untuk menimbulkan manfaat lain kepada sesama manusia dan untuk memperoleh ridha Allah (Inggriani \& Nafik HR, 2015).

\section{METODE}

Pendekatan penelitian yang digunakan dalam penelitian ini adalah pendekatan deskriptif. Pendekatan deskriptif adalah pendekatan dengan mendeskripsikan suatu kejadian atau fenomena untuk memperoleh hasil yang akurat dan di interpretasikan dengan kata-kata tertulis (Soendari, 2012). Dengan menggunakan library research atau study literatur yaitu mencari sumber referensi teori yang sesuai dengan kasus atau sebuah permasalahan yang dikemukakan (Surani, 2019).

Penelitian ini juga menggunakan penelitian kualitatif deskriptif. Alasan lain penggunaan metode penelitian kualitatif deskriptif pada penelitian ini adalah penelitian ini tidak bertujuan melakukan uji hipotesis dengan metode statistik atau ekonometri (Gimeno-Gilles et al., 2016). Tujuan dari penelitian ini membahas mengenai bagaimana implementasi pengelolaan keuangan secara Islam pada keluarga muslim di masa pandemi covid-19. Pertanyaan 'bagaimana' lebih tepat menggunakan pendekatan kualitatif karena dalam penelitian ini peneliti tidak memiliki peluang untuk melakukan kontrol terhadap obyek penelitian

Berdasarkan uraian diatas maka untuk menganalisis data menggunakan data yang telah diperoleh dalam bentuk penelitian sebelumnya kemudian data tersebut dianalisis di kategorisasi dan ditafsirkan dengan menggunakan perspektif dengan menggunakan analisis dokumenter.

\section{HASIL DAN PEMBAHASAN Manajemen Keuangan}

Manajemen menurut pendapat George Terry itu merupakan pencapaian tujuan yang ditetapkan terlebih dahulu dengan mengarahkan dan menggunakan orang lain. Sedangkan menurut Siagian dalam bukunya Hames S. F. Stoner menyebutkan bahwa manajemen adalah tujuan yang ingin dicapai dengan mengarahkan orang lain yaitu dengan membimbing dan mengawasinya agar bersedia melakukan kegiatan yang telah ditetapkan (Siregar, 2020).

Pengertian manajemen keuangan menurut Keown adalah "financial management is concerned with the maintenance and creation of economic value or wealth". Sedangkan pengertian manajemen menurut Sutrisno yakni "manajemen keuangan adalah semua aktifitas perusahaan yang berhubungan dengan usaha-usaha mendapatkan dana perusahaan dengan biaya yang murah, serta untuk mengalokasikan dana tersebut secara efisien". Manajemen keuangan adalah menyangkut tugas manajer keuangan dalam perusahaan. Manajer keuangan secara aktif mengatur urusan dari berbagai macam tipe dari bisnis keuangan, dan bukan keuangan pribadi dan masyarakat, besar dan kecil, mencari keuntungan atau tidak mencari keuntungan. Mereka melakukan berbagai perencanaan keuangan, sebagaimana dalam skala terkecil sebuah bentuk organisasi di masyarakat yaitu keluarga, peran manajer keuangan sepenuhnya dipegang oleh seorang istri (Inggriani \& Nafik HR, 2015). Dalam pengelolaan keuangan tidak hanya sekedar transfer informasi tentang perekonomian dari sebuah rumah tangga, tetapi harus menjadi suatu proses pembentukan kepribadian yang berkarakter. Pengelolaan ini mempunyai tujuan membentuk manusia yang beriman dan bertakwa serta menjalankan kehidupan yang sesuai syariat Islam (ARNESIH, 2016). 


\section{Manajemen Keuangan Keluarga}

Manajemen keuangan merupakan tindakan administratif yang berhubungan dengan kegiatan perencanaan anggaran, penyimpanan, penggunaan, pencatatan dan pengawasan keluar masuknya uang/dana organisasi. Pengelolaan keuangan, dapat dilakukan oleh siapa saja mulai dari tingkat paling kecil berupa individu, kelompok, hingga keluarga.

Keluarga berfungsi pada seluruh aspek dalam kehidupan, diantaranya fungsi biologis, fungsi pemeliharaan, fungsi ekonomi, fungsi keagamaan, fungsi sosial, dan sebagainya. Dalam perjalanan sebuah keluarga tentu sangat dipengaruhi oleh masalah keuangan. Dengan pengelolaan keuangan yang baik maka akan tercipta pemenuhan kebutuhan hidup keluarga yang baik pula. Dan mengatur keuangan sesungguhnya tidak hanya mengatur uang masuk dan keluar saja yang harus dipikirkan dalam memenuhi kebutuhan dasar manusia, namun juga harus dipikirkan dana mana yang akan memenuhi kebutuhan ketika memasuki usia non produktif untuk masa yang akan datang (Siregar, 2020).

Jadi dapat disimpulkan bahwa manajemen keuangan keluarga adalah suatu seni dalam mengelola keuangan keluarga melalui orang lain untuk mencapai tujuan yang bermanfaat, sehingga keluarga tersebut menjadi keluarga yang sejahtera. Management keuangan keluarga merupakan keharusan yang tidak bisa di tawar lagi, karena pengelolaan keuangan keluarga memiliki implikasi yang lebih luas sebab yang terlibat bukan hanya diri sendiri, tetapi istri/suami, anak-anak bahkan orang tua maupun mertua (Rodhiyah, 2012).

Pengelolaan keuangan keluarga sangat penting bagi kesejahteraan setiap individu dan keluarga dalam kehidupan sehari-hari. pengelolaan keuangan Islami adalah pengelolaan dengan menentukan skala prioritas dan anggaran belanja rumah tangga. Dalam ajaran Islam seorang muslim dianjurkan untuk mengelola keuangan sesuai dengan ajaran Allah untuk memastikan kesuksesan dalam hidup. Sebuah keluarga muslim dalam mengelola pembelajaran pada dasarnya harus berprinsip pada pola konsumsi Islami, yaitu berorientasi kepada kebutuhan (need) serta mendahulukan manfaat (utility) dan berusaha mengurangi keinginan yang berlebihan (Gimeno-Gilles et al., 2016).

Untuk mencapai komunikasi keuangan yang baik, menurut Dr. Setiawan Budi Utomo, mengatakan, bahwa seluruh anggota keluarga harus memiliki satu pengertian yang sama tentang tiga prinsip dasar dari pengelolaan keuangan rumah tangga Muslim (Kusumawat, 2011) yaitu: (1) Berupaya mencari nafkah yang halal dan thayyib. Suami, istri maupun anak-anak harus saling mengingatkan dan mengontrol apa yang mereka dapat dalam rumah tangga. (2) Hemat dan ekonomis salah satu langkah hebat orang tua dalam mendidik anak adalah berhemat dan tidak konsumtif. Di sini harus ada proses komunikasi, komitmen bersama dan contoh nyata dari orang tua kepada anak. (3) Membiasakan diri menabung untuk dunia akhirat. Setiap anggota keluarga harus sepakat untuk selalu menabung dan bersedekah dalam kondisi apapun.

Manajemen keuangan keluarga itu sangat penting tidak hanya pada masa pandemi covid-19 seperti sekarang ini, di kondisi normal pun manajemen keluarga itu sangat penting untuk mengetahui kondisi keuangan di dalam keluarga dan kita terapkan dalam kehidupan kita sehari hari. Menurut ajaran agama Islam secara fitrah kewajiban dalam memberi nafkah/ kebutuhan merupakan tanggung jawab suami. Namun, dalam praktiknya harus dilakukan keterbukaan antara pasangan keluarga tentang dari mana dan berapa besar penghasilan yang diperoleh oleh suami, sehingga ibu rumah tangga akan tergerak untuk berusaha mengelola pendapatan suami sebaik mungkin dalam memenuhi segala kebutuhan keluarga. Komitmen juga merupakan hal sangat penting sekali dilakukan antara suami dan istri dalam pengelolaan keuangan agar tidak terjadi miskomunikasi yang dapat menimbulkan pertengkaran dalam rumah tangga tersebut (Siregar, 2020)

Andai di dalam rumah tangga apabila tidak bisa mengelola keuangan dengan baik yang akan terdampak bukan diri kita sendiri tetapi seluruh anggota keluarga. Sebagai ibu rumah 
tangga yang biasanya dinafkahi oleh suami dengan nafkah yang serba berkecukupan, ternyata tiba-tiba sang pencari nafkah telah tiada, apa yang harus kita lakukan sebagai seorang istri walaupun misalnya sang pencari nafkah meninggalkan harta atau bekal yang cukup banyak tetapi apabila kita tidak bisa mengelola nya itu akan cepat habis, jadi dengan demikian manajemen keuangan kelurga itu sangat penting untuk kita ketahui dan kita terapkan dalam kehidupan kita keseharian dalam rumah tangga.

Menurut (Handayani, 2013) beberapa kunci untuk mengelola keuangan secara sederhana: (1) Pahami portfolio keuangan keluarga. Jangan sampai tidak tahu isi tabungan, jumlah tagihan listrik, telepon, servis mobil, belanja, biaya periksa dokter dan lainnya. Harus mengetahui jumlah hutang kartu kredit, pinjaman bank atau cicilan rumah dan mobil. (2) Susun rencana keuangan atau anggaran. Rencana keuangan yang realistis membantu bersikap obyektif soal pengeluaran yang berlebihan. Tak perlu terlalu ideal, sehingga lupa kebutuhan diri sendiri. Tak ada salahnya memasukkan kebutuhan pergi ke salon dan lain-lainnya. Yang penting, anggarkan jumlah yang realistis dan harus patuh dengan anggaran tersebut. (3) Pikirkan lebih seksama pengertian antara "butuh" dan "ingin". Tak jarang kita membelanjakan uang untuk hal yang tak terlalu penting atau hanya didorong keinginan, bukan kebutuhan. (4) Hindari hutang. Godaan untuk hidup konsumtif semakin besar. Tumbuhkan kebiasaan keuangan yang sehat dimulai dari yang sederhana, seperti tak memiliki hutang konsumtif. (5) Meminimalkan belanja konsumtif. Bertemu teman lama untuk bertukar pikiran di kafe terkadang memang perlu, tapi tidak berarti harus melakukannya di setiap malam minggu. Gunakan pengeluaran ini untuk menabung atau memenuhi kebutuhan lain. (6) Tetapkan tujuan atau cita-cita finansial. Susun target keuangan yang ingin diraih secara berkala, bersama pasangan. Tetapkan tujuan spesifik, realistis, terukur dan dalam kurun waktu tertentu. (7) Tabungan, menabung, menabung. Ubah kebiasaan dan pola pikir. Segera setelah menerima gaji, sisihkan untuk tabungan dalam jumlah yang telah direncanakan sesuai tujuan atau cita-cita finansial keluarga. (8) Berinvestasi lah. Tentu tidak akan puas dengan hanya menunggu tabungan meningkat. Padahal cita-cita untuk keluarga "selangit". Inilah saat yang tepat untuk juga memikirkan investasi. Kini bentuknya macam-macam. Takut akan risiko investasi?! Tak perlu khawatir, hanya perlu belajar pada ahlinya. Konsultasikan keuangan dengan ahli yang handal. (9) Ucapkan selamat tinggal pada rekening terpisah. Ketika telah menikah, uang bukan milikmu atau milikku, tapi milik berdua. Buatlah satu rekening giro atau tabungan untuk tujuan keuangan bersama. (10) Perbarui penerima manfaat. Ubah semua penerima manfaat pada polis asuransi, program pensiun, reksadana, dan surat berharga lainnya dengan nama pasangan. Hal ini sebenarnya tidak mutlak dilakukan, terutama apabila belum mempunyai anak. Namun terkadang sangat diperlukan, terutama apabila tidak punya orang lain lagi untuk dipercaya. (11) Buat kesepakatan tentang pengeluaran keluarga. Bisa dicoba untuk mendiskusikan dengan pasangan tentang pendekatan dan kebiasaan untuk menangani uang. Apakah satu orang pemboros dan satu lagi hemat? Buatlah aturan untuk menangani perbedaan, mungkin menetapkan batas pengeluaran bulanan untuk setiap orang atau menjanjikan untuk menyimpan sejumlah tertentu setiap bulan untuk mencapai suatu tujuan bersama. (12) Konsolidasi kartu kredit. Hindari memiliki kartu kredit lebih dari yang dibutuhkan. Hal ini juga membuat lebih mudah untuk melacak pengeluaran rumah tangga. (13) Beli asuransi jiwa. Jika pendapatan dipakai untuk membayar pengeluaran bulanan dan sebagian besar pasangan melakukan pastikan memiliki asuransi jiwa yang cukup untuk saling melindungi. Hal ini mutlak dilakukan apabila sudah mempunyai tanggungan, misalnya anak atau orang tua.

Berikut langkah-langkah pengelolaan keuangan keluarga. Menurut (BI) Bank Indonesia dalam(Hidayah et al., 2019) terdapat langkah- langkah dalam pengelolaan keuangan kelurga sebagai berikut : (1) Pencatatan Aset/Harta yang Dimiliki. Setiap orang pasti memiliki aset/harta yang dicatat sebagai harta produktif maupun konsumtif. Harta produktif adalah harta 
yang memberikan penghasilan rutin atau keuntungan pada saat harta tersebut dijual kembali. (2) Pencatatan Semua Pemasukan dan Pengeluaran. Setelah mencatat semua aset/harta, mendapatkan informasi tentang posisi keuangan saat ini. Hal ter-sebut berguna dalam melakukan lang-kah selanjutnya, yaitu mencatat semua pemasukan dan pengeluaran. Kegiatan mencatat semua pemasukan dan pengeluaran akan memberikan informasi ten-tang banyaknya uang yang telah masuk dan yang dikeluarkan. Hal tersebut men-jadi pertimbangan bagi seseorang untuk mengontrol pengeluaran-pengeluaran yang tidak perlu. Pencatatan pemasukan dan pengeluaran juga membantu untuk mengetahui frekuensi pemasukan dan pengeluaran untuk suatu pos tertentu, sehingga dapat membedakan pengeluaran mana yang termasuk kebutuhan dan mana yang termasuk keinginan. (3) Identifikasi Pengeluaran Rutin, Bulanan, dan Tahunan. Setiap orang atau keluarga biasanya mempunyai pola pengeluaran yang mirip dari bulan ke bulan, termasuk dari tahun ke tahun. Setelah memiliki catatan pengeluaran, coba identifikasi apa saja yang menjadi pengeluaran rutin dan bagaimana frekuensinya. (4) Menyusun Rencana Pengeluaran (budgeting). Pada tahapan ini, para pengelola keuangan diminta untuk dapat melakukan perencanaan terkait pengeluaran keuangan yang akan dilakukan. Hal ini juga termasuk di dalamnya mengatur prioritas. Dalam ajaran Islam menurut (ARNESIH, 2016) Pengeluaran terdiri dari kebutuhan pokok harian 50\%; Zakat/Infak/Sedekah $21 / 2 \%$ ( jika zakat, jika infak sedekah seikhlasnya); kredit 20\%; investasi $20 \%$; UGD (uang gawat darurat) $7 \frac{1}{2} \%$. (5) Menabung secara periodik. Menabung sebaiknya dilakukan secara berkala adanya solusi yang ditawarkan berupa peningkatan pengetahuan masyarakat terkait pengelolaan keuangan keluarga, diharapkan dapat mengurangi tingkat konsumerisme masyarakat dan membiasakan masyarakat untuk mulai menabung. Dalam Al-Qur'an terdapat ayat yang secara tidak langsung telah memerintahkan kaum muslimin untuk mempersiapkan hari esok secara lebih baik). Firman Allah Swt dalam Surat An-Nisaa' (4:9) (Damayanti, 2017). Dan semua pendapatan yang tidak dikonsumsi itu ditabung dan atau dipergunakan untuk investasi. Semakin tinggi konsumsi berarti semakin kecil tabungan dan sebaliknya semakin besar tabungan akan mengurangi tingkat konsumsi. Dalam hal ini berarti penting diperhatikan bahwa perilaku konsumen dalam melakukan konsumsi yang diharapkan juga mampu memenuhi keperluan atau kebutuhan di masa mendatang diantaranya melalui investasi dan tabungan (Rahayu et al., 2021).

Selanjutnya akan coba menguraikan langkah-langkah dalam pengelolaan keuangan keluarga, yaitu : (1) Mencatat semua pengeluaran yang wajib dikeluarkan per bulannya. (2) Mencatat semua pengeluaran yang bisa iya atau tidak per bulannya. (3) mencatat semua passive income. (4) Mencatat semua active income. (5) Menjumlahkan pengeluaran wajib perbualan dan pengeluaran bisa tidak per bulannya. (6) Menjumlah passive income dan active income. (7) Menghitung selisih antara hasil pengeluaran wajib perbualan dan pengeluaran bisa tidak per bulannya dan passive income dan active income. (8) Alokasikan dana, untuk hari tua 10 persen (uang aman, atau istilahnya sebagian orang uang mati yang tidak akan kita pakai kalau bukan antara hidup dan mati ), 20 persen cadangan untuk tumbuh, dan $70 \%$ untuk biaya sehari hari atau model kedua adalah $10 \%$ hari tua, $10 \%$ untuk amal, $10 \%$ untuk pendidikan, $10 \%$ untuk cadangan tumbuh, dan $60 \%$ untuk biaya sehari hari yang di habiskan.

Kunci keberhasilan dalam mengelola keuangan keluarga dalam keadaan sehat yaitu: Pada dasarnya mengukur kesehatan keuangan Rumah tangga adalah bagaimana cara kita berkomitmen untuk melaksanakan apa yang telah direncanakan diatas, karena jika kita tidak bisa komitmen terhadap keuangan Rumah tangga, maka keuangan rumah tangga dalam keadaan sakit, jika kita dapat melaksanakan perencanaan keuangan sesuai yang kita rencanakan seperti contoh diatas maka keuangan Rumah tangga kita dalam keadaan sehat. Allah swt, telah memberikan kecukupan harta pada manusia sesuai firman Nya dalam Qur'an surat adhuha ayat 
8 yang artinya "Dan Dia mendapatimu sebagai seorang yang kekurangan, lalu Dia memberikan kecukupan ( QS, Adh-Dhuha: 8 )

\section{PENUTUP}

Berdasarkan pembahasan dan analisis yang dikemukakan diatas setelah melakukan penelitian tentang manajemen keuangan keluarga di era covid 19 maka dapat disimpulkan bahwa manajemen keuangan keluarga itu sangat penting karena kita tidak hidup sendiri melainkan kita adalah bagian dari keluarga. Pengelolaan keuangan keluarga umumnya dapat dilakukan sesuai dengan proses manajemen yaitu adanya perencanaan yang matang, implementasi yang ketat, dan evaluasi yang terukur. Pengelolaan keuangan keluarga sangat penting bagi kesejahteraan setiap individu dan keluarga dalam kehidupan sehari-hari. pengelolaan keuangan Islami adalah pengelolaan dengan menentukan skala prioritas dan anggaran belanja rumah tangga. Langkah-langkah yang kita lakukan dalam mengelola keuangan keluarga adalah sebagai berikut : (1) mencatat aset/harta yang dimiliki, (2) mencatat semua pemasukan dan pengeluaran, (3) identifikasi pengeluaran rutin, bulanan, dan tahunan, (4) menyusun rencana pengeluaran, (5) menabung secara periodik. Kunci keberhasilan dalam mengelola keuangan keluarga dalam keadaan sehat yaitu: Pada dasarnya mengukur kesehatan keuangan Rumah tangga adalah bagaimana cara kita berkomitmen untuk melaksanakan apa yang telah direncanakan diatas, karena jika kita tidak bisa komitmen terhadap keuangan Rumah tangga, maka keuangan rumah tangga dalam keadaan sakit, jika kita dapat melaksanakan perencanaan keuangan sesuai yang kita rencanakan.

\section{DAFTAR PUSTAKA}

Abdul Ghoffar. (n.d.). 35 MANAJEMEN DALAM ISLAM (PERSPEKTIF AL-QUR'AN DAN HADITS) Oleh : Abdul Goffar $\square .35-58$.

Al Hamat, A. (2018). Representasi Keluarga dalam Konteks Hukum Islam. YUDISIA : Jurnal $\begin{array}{lllll}\text { Pemikiran Hukum Dan Hukum } & 139 .\end{array}$ https://doi.org/10.21043/yudisia.v8i1.3232

ARNESIH, A. (2016). Strategi Manajemen Keuangan Dalam Rumah Tangga (Berbasis Ekonomi Syariah ). HISTORIA: Jurnal Program Studi Pendidikan Sejarah, 1(1), 1-11. https://doi.org/10.33373/his.v1i1.387

Damayanti, S. (2017). Pengaruh Pandangan Islam, Pelayanan Dan Keamanan Terhadap Minat Nasabah Untuk Menabung Di Bank Syariah Mandiri Cabang X. Jurnal Manajemen Dan Pemasaran Jasa, 9(1), 17. https://doi.org/10.25105/jmpj.v9i1.1412

Gimeno-Gilles, C., Lelièvre, E., Viau, L., Malik-Ghulam, M., Ricoult, C., Niebel, A., Leduc, N., Limami, A. M., Schmidt-Lebuhn, A. N., Fuchs, J., Hertel, D., Hirsch, H., Toivonen, J., Kessler, M., Loureiro, J., Lavania, U. C. U. C., Srivastava, S., Lavania, S., Basu, S., ... Yao, J. L. (2016). No 主観的健康感を中心とした在宅高齢者における 健康関連指標 に関する共分散構造分析Title. $\quad$ Euphytica, 22280. http://dx.doi.org/10.1016/j.jplph.2009.07.006

Gustiawati Mukri, S., \& Mulyadi Kosim, A. (2017). Metode Pengelolaan Keuangan Keluarga Secara Islami (Persepsi Komunitas Dosen dan Karyawan UIKA Bogor). Prosiding LPPM UIKA Bogor, 171-188. http://pkm.uika-bogor.ac.id/index.php/prosiding/article/view/234

Hahury Fransisca, H. D. S. (2021). Strategi Penghidupan Rumah Tangga Pedesaan dalam Menghadapi Dampak Pandemi Covid-19. Jurnal Pengabdian Pada Masyarakat, Vol 6 No 2 (2021), 343-350. http://ppm.ejournal.id/index.php/pengabdian/article/view/817/401

Handayani, N. (2013). Cara Sederhana Mengelola Keuangan Keluarga. Jurnal Keluarga Sejahtera, 11(22), 29-34. http://ppkmindonesia.com/artikel/klinik/item/77-carasederhana-mengelola-keuangan-keluarga 
Hidayah, R., Suryandari, D., \& Purwanti, A. (2019). Pengelolaan Keuangan Keluarga dalam Rangka Peningkatan Masyarakat Mandiri dan Berperan dalam Peningkatan Literasi Keuangan Indonesia (Otoritas Jasa Keuangan). Jurnal Abdimas, 23(2), 165-169.

Inggriani, L., \& Nafik HR, M. (2015). Bagaimana Peran Istri Dalam Mencapai Maqashid Syariah: Istri Sebagai Manajer Keuangan. Jurnal Ekonomi Syariah Teori Dan Terapan, 2(12), 1036. https://doi.org/10.20473/vol2iss201512pp1036-1051

Kusumawat, D. (2011). Pengelolaan Keuangan dalam Keluarga dari Sudut Pandang Islam. Gema Eksos. 2(6), 175-186.

Rahayu, M. A., Widowati, M., \& Handayani, J. (2021). Analisis Pengaruh Perilaku Konsumtif, Motivasi, Kelompok Referensi dan Kualitas Layanan Terhadap Keputusan Menabung. Al Maal: Journal of Islamic Economics and Banking, 2(2), 143. https://doi.org/10.31000/almaal.v2i2.3201

Ramli, M., \& Apriyanto, M. (2020). Perekonomian Keluarga Di Masa Pandemi Covid-19. Selodang Mayang: Jurnal Ilmiah Badan Perencanaan Pembangunan Daerah Kabupaten Indragiri Hilir, 6(3), 145-152. https://doi.org/10.47521/selodangmayang.v6i3

Rodhiyah. (2012). Manajemen Keuangan Keluarga Guna Menuju Keluarga Sejahtera. FORUM: Majalah Pengembangan Ilmu Sosial, 1, 28-32.

Rohaniah, Y., \& Rahmaini, R. (2021). Sosialisasi Manajemen Keuangan Keluarga pada Masa Pandemi Covid-19. ABDI MOESTOPO: Jurnal Pengabdian Pada Masyarakat, 4(01), 4549. https://doi.org/10.32509/am.v4i1.1371

Siregar, B. G. (2020). Ibu Rumah Tangga Dalam Manajemen Keuangan Keluarga. Jurnal Kajian Gender Dan Anak, 3(1), 16-32. https://doi.org/10.24952/gender.v3i1.2255

Soendari, T. (2012). M ET ODE PEN EL I T I A N DESK RI PT I F Ol e h T j u t j u So e n d a r i. Stuss, Magdalena \& Herdan, Agnieszka 17.

Surani, D. (2019). Studi Literatur: Peran Teknolog Pendidikan dalam Pendidikan 4.0. Prosiding Seminar Nasional Pendidikan FKIP, 2(1), 456-469.

https://tafsirweb.com/7557-quran-surat-as-sajdah-ayat-5.html diakses pada 1 oktober 2021 pukul 21:00.

https://tafsirweb.com/10816-quran-surat-al-hasyr-ayat-18.html diakses pada 1 oktober 2021 pukul 22:00. 